\title{
Service Quality Status and Customer Satisfaction in Commercial Banking Sector of Nepal
}

\author{
Makshindra Thapa, PhD \\ Lecturer, Tribhuvan University \\ Visiting Faculty, Nesfield International College \\ Email: tmakshindra@yahoo.com
}

\begin{abstract}
The basic intent of this study is to reveal existing level of service quality of some Nepalese commercial banks. The customer perception to measure bank services quality within five dimensions; tangibles, reliability, responsiveness, assurance and empathy are considered as to service quality model introduced by Parashuranman et. al. in 1988. This study is a descriptive in nature and uses primary data collected through personally administered questionnaire survey with customers of some selected commercial banks including public and private banks. The questionnaire includes 22 questions in total for five dimensions. The sample size of the study is 82 respondents of the banks selected on convenience basis. The analysis consist descriptive statistics and t-test in order to meet the study objectives.
\end{abstract}

Keywords: Service quality, SERVQUAL model, reliability analysis, banking sector

\section{Introduction}

Quality and quality management are one of the central issues of contemporary management of all organizational settings. Managing quality now days is considered as mandatory and strategic tool to conduct successful business operations. The issues and methods of quality have been originated by various leading quality gurus like Juran, Deming, and Crosby. In this context, Crosby (1979) has defined quality as conformance to requirement. In every product or service some technical, legal and market related requirements are inherent and effective maintenance of such requirements express presence of quality. Most of the Japanese firms follow zero defect philosophy of quality. The zero defect (or defect-free) product and service that emphasizes doing the things right for the first time by eliminating possible defects in goods and services.

Garvin (1983) defines quality by counting the incidence of internal (before product leaves the factory) and external failure (after the product is installed). Organization 
those fail to maintain customer requirements and quality standards loose market and business at all. Many studies are evident of positive return of quality management. Quality helps firms in gaining more market share and return on equity, lowering production cost, improving productivity and achieving more competitive advantages.

The services sector has received a substantial growth during the last three decades in Nepal. Due to the pressure of globalization and liberalization, Government of Nepal adopted liberal policies in relation to financial institutions including commercial banks especially after the democratic movement of 1990s. With the change in government policy, many private and joint venture banks were established. At present 28 commercial banks are in operation with hi-tech banking products. The banking industry of Nepal faces intense competition for customers and thus managing better service quality has become a central issue. These changing market scenarios have left the banks no other option but to adopt the more service quality oriented approach to achieve their objectives.

This study intends of reveal existing service quality being offered by some Nepalese commercial banks within five service quality dimensions; tangibles, reliability, responsiveness, assurance and empathy.

\section{Review of the Literature}

\subsection{The service quality}

Service quality is more comprehensive and human resource concentrated than of product quality. Due to rise of service sectors as dominant in global economy, the concept of service quality has received a great deal of attention from both academicians and practitioners throughout the past three decades. Service quality has been defined variously as per diverse nature of services. Gronroos (1984) defined service quality as the outcome of the comparison that consumers make between their expectations and perceptions. Similarly, Parasuraman, Zeithaml and Berry (1985) defined service quality as the difference between customer expectations and perception of actual service. Both of these definitions suggest service quality as meeting customer expectations and requirements.

Service quality is provided to the customer is determined by many factors. Gronroos (1983) has stated that service quality perceived by customers has two dimensions as; technical quality which emphasizes 'what' customer actually receives from service 
and functional quality emphasizes 'how' service is delivered. Similarly, behaviour of employees and speed of service delivery are examples of other important functional qualities.

Measuring and managing service quality is little complicated task than of product quality. In the case of tangible goods, the measurement of quality is an easy task due to maintenance of the uniform quality standards consistently to all units of production as per the industry or legal requirements. In contrast, service quality is an elusive and abstract construct that is difficult to measure (Cronin \& Taylor, 1992). The three basic characteristics of service that create a challenge for service providers are; intangibility, heterogeneity and inseparability. Service quality therefore covers broad area concerned with managing quality elements in services provided to the consumers.

\subsection{Measurement of service quality}

Measurement of service quality itself is a challenging task which seeks careful analysis and understandings of customer expectation. It is assumed that quality is high when performance exceeds expectation and quality is low when performance does not meet expectation. The most common model for measuring service quality is the SERVQUAL model. It was developed by Parasuraman et al. in 1985 and was later refined. Initially the SERVQUAL model had 10 dimensions of service quality, which were later reduced to five dimensions. The quality of services is evaluated by the consumers using these five dimensions. These service quality measurement dimensions consist;

- Reliability denotes to the ability of a service provider to provide accurate and dependable service to the customers.

- Assurance is concerned with the quality of firm employees to inspire trust and confidence of the customers towards the firm and its services.

- Tangibles represent the general outlook of the firm in terms of its physical surrounding and appearance of employees.

- Empathy as a quality dimension denotes to the individualized attention provided to customers by the firm.

- Responsiveness is the willingness of the firm staff to help customers by providing prompt service. 


\subsection{Service quality in banking sector}

A significant corpus of literature has emerged in recent years with the growth of the banking industry worldwide. Service quality is needed in a competitive market; banking service providers are expected to achieve a high degree of customer satisfaction through offering customer expected service qualities.

Afroz (2019) attempted to determine the effect of service quality on customer satisfaction both from public and private banks in Tangail city, Bangladesh. She applied both descriptive and inferential statistics to analyze opinions of 200 customers. The result indicated significant impact of tangibles, assurance and reliability dimensions and insignificant effect of empathy and responsiveness dimensions on customer satisfaction.

Alabboodi (2019) conducted a study with aims to investigate the relationship of customer satisfaction towards service quality in Iraqi banks. The sample for his study consisted of 323 customers of Iraqi banks in Bagdad. The results indicated that service quality components namely assurance, reliability, tangibility, and empathy effect positively and significantly on customer satisfaction. However the responsiveness dimension was found statistically insignificant.

Ashraf and Venugopalan (2018) carried a study with the aim of comparing the quality of service between public and private sector banks in Kerala, India applying SERVQUAL model introduced by Parashuranman et. al. The results indicated positive effect of service quality dimensions on customer satisfaction and there was no significant difference observed between public sector and private sector bank in service quality dimensions and level of customer satisfaction.

Ahemad (2017) studied level of service quality in Islamic and Conventional banks of Pakistan based on SERVQUAL model using questionnaire survey. It is found that Islamic banks have Service Quality gap as compared to Conventional banks on the five dimensions i.e. Tangibility, Reliability, Convenience Competence and Satisfaction. His result revealed that the customers were found satisfactory on all five dimensions of service quality.

Van and Lee (2012) carried on a study with objectives of assessing the service quality dimensions (tangibility, reliability, responsiveness, assurance, and empathy) and to examine the relationship between service quality and customer satisfaction in the retail banking sector in Vietnam. The result of their study indicated that the five quality dimensions were existed as satisfactory and were significantly interrelated. 
The service quality was found to be positively correlated with customer satisfaction in the retail banking sector in Vietnam. Similarly, Khondaker and Mir (2011) concluded a positive and significant effect of service quality dimensions on customer satisfaction in their study of Bangladeshi banking sector.

This study has applied the SERVQUAL model to evaluate existing service quality of some selected Nepalese banks as evaluated by the consumers within five dimensions of service quality.

\section{Methods}

\subsection{Research design and data collection procedure}

This study embodies the descriptive research design aimed to describe the service quality elements perceived by the customers of selected commercial banks of Nepal. To collect customer opinion a customer survey was conducted in different items of banking service quality a standardized questionnaire has been administered using the modified form of SERVQUAL model. The questionnaire consisted of 22 service quality related measures divided into five dimensions of SERVQUAL as indicated in Table 1 The items in the questionnaire were measured on a 5-point Likert like scale that ranging from 1 = "Very Unsatisfied" to 5 = "Very Satisfied".

Table 1

Frequency of Service Quality Measures Applied in the Questionnaire

\begin{tabular}{ll}
\hline SERVQUAL dimensions & No of items \\
\hline Tangibles & 5 \\
Reliability & 5 \\
Responsiveness & 4 \\
Assurance & 4 \\
Empathy & 4 \\
Total & 22 \\
\hline
\end{tabular}


The respondents were bank customers in the form of loan seekers and depositors selected randomly from two category of four the commercial banks of Nepal. The customers of two public banks selected were of Nepal Bank limited and Rastriya Banijya Bank Limited and the private banks considered for the survey were Nepal investment Bank and Citizens International bank Limited. The personal administered survey consisted, altogether 300 questionnaires distributed to the equally to the bank customers randomly selected in convenience basis within the head office and branches inside of Kathmandu valley. Out of distributed questionnaires, 180 responses were received and only 164 usable responses were considered for the analysis. The response rate was 55\%. The data collection procedure was done during three months period of January- March 2019.

\subsection{Reliability of the instruments}

Reliability test is a judgment of the degree of stability and consistency between multiple measurements of a variable. The calculated Cronbach's alpha for 22 items of measures within 5 dimensions is 798 . The result has suggested that the service quality dimensions and their independent measures pose quality of stability and consistency as the computed value of alpha is the commonly accepted measurement technique with a generally agreed lower limit of 0.7 .

\subsection{Data analysis}

The collected data from the survey were processed and presented in tables for the purpose of analysis. With use of SPSS program, reliability analysis was done measure reliability of the research instruments. Descriptive statistics used to measure level of service quality divided into five dimensions of tangibles, reliability, responsiveness, assurance and empathy. To make inferential analysis T-Test applied to reveal answers to the research objectives.

\section{Results and Discussions}

\subsection{Tangibles SERVQUAL dimension of the banks}

One of the dimensions of service quality related to banking service used is tangibles. Altogether five measures have been applied to assess consumer perception about tangibles of the banks. These measures are; bank infrastructure, bank equipment, physical facilities, branch network and bank documents. Table 2 depicts frequencies of responses and descriptive statistics. 
Table 2

Descriptive Statistics Service Quality Dimension of Tangibles

\begin{tabular}{|c|c|c|c|c|c|c|c|c|c|}
\hline Tangibles Measures & $\sum_{\Sigma}^{\Xi}$ & 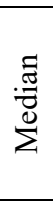 & 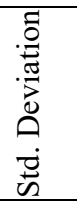 & 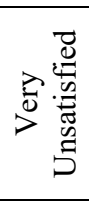 & 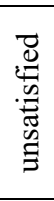 & 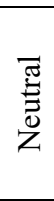 & 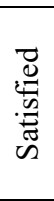 & 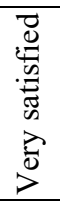 & 要 \\
\hline $\begin{array}{l}\text { Visually appealing Infrastructures } \\
\text { of the bank. }\end{array}$ & 3.8 & 4 & 0.57 & - & 10 & 46 & 88 & 20 & 164 \\
\hline $\begin{array}{l}\text { Hi-tech and up-to-date equipment } \\
\text { of the bank like ATM and Mobile } \\
\text { banking. }\end{array}$ & 3.6 & 4 & 0.68 & 8 & 20 & 64 & 60 & 12 & 164 \\
\hline Banks physical facilities & 3.6 & 4 & 0.7 & - & 16 & 36 & 86 & 26 & 164 \\
\hline $\begin{array}{l}\text { Wide network of branches and } \\
\text { ABBS services }\end{array}$ & 3.7 & 4 & 0.61 & 2 & 10 & 62 & 70 & 20 & 164 \\
\hline $\begin{array}{l}\text { Statements and broachers are } \\
\text { visually appealing }\end{array}$ & 3.8 & 4 & 0.82 & - & 8 & 48 & 88 & 20 & 164 \\
\hline Group Mean & 3.68 & & & & & & & & \\
\hline
\end{tabular}

The result indicted for customer's positive responses towards all of five used tangibles measures. The presence of appealing infrastructure as well as bank statement and brochures has highest mean values. The customers also have accepted that the banks have wide range of branches with ABBS services. The physical facilities and different equipments also seemed to be satisfactory. The group mean for this dimension is 3.68 which is evident of the satisfactory level of bank tangibles of bank physical facilities as responded by the customers. The respondents have reflected their satisfaction with the service quality of existing tangibles of the banks.

\subsection{Reliability SERVQUAL dimension of the banks}

Reliability is other dimensions applied in this study to access the level of service quality of the banks. This dimension has covered five areas of measures as; timely services, sincerity in problem solving, right service time, error-free records and convenient operating hours. Table 3 depicts responses of 164 customers of the banks about these measures and descriptive statistics. 
Table 3

Descriptive Statistics Reliability Service Quality Dimension

\begin{tabular}{|c|c|c|c|c|c|c|c|c|c|}
\hline Reliability Measures & $\stackrel{\Xi \Xi}{\Sigma}$ & 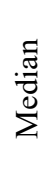 & 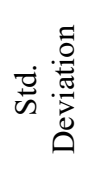 & 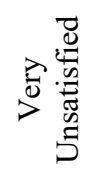 & 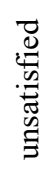 & $\begin{array}{l}\bar{\pi} \\
\stackrel{0}{0} \\
\ddot{Z}\end{array}$ & 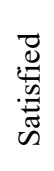 & $>\stackrel{D}{D}$ & 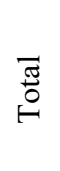 \\
\hline $\begin{array}{l}\text { Timely services as per } \\
\text { promise }\end{array}$ & 3.7 & 4 & 0.898 & 2 & 17 & 42 & 79 & 24 & 164 \\
\hline $\begin{array}{l}\text { Sincere interest in } \\
\text { solving customer } \\
\text { problems }\end{array}$ & 3.3 & 3 & 0.949 & 9 & 26 & 51 & 62 & 16 & 164 \\
\hline $\begin{array}{l}\text { Performing service } \\
\text { right the first time }\end{array}$ & 3.6 & 4 & 0.941 & 6 & 12 & 42 & 81 & 23 & 164 \\
\hline $\begin{array}{l}\text { Error free record } \\
\text { system }\end{array}$ & 3.3 & 3 & 0.887 & 6 & 21 & 69 & 59 & 9 & 164 \\
\hline Operating hours. & 3.8 & 4 & 0.889 & 2 & 14 & 36 & 83 & 29 & 164 \\
\hline Group Mean & 3.52 & & & & & & & & \\
\hline
\end{tabular}

The results have suggested that most of the customers of these banks are satisfied with reliable services provided as group mean of this dimension is 3.61 and almost of the respondents have showed their satisfaction for all five reliability measures. Among five measures of this dimension, banks perform services right the first time, convenient operating hours and timely services of banks as promise are respectively more satisfied service items by the customers. However banks error free record and sincere interest in solving customer problems seemed to be less satisfactory to the customer comparatively. The results suggest to banks having reliable services.

\subsection{Responsiveness SERVQUAL dimension of the banks}

The third service quality assessment dimension used in the study is responsiveness level of the banks especially concerned with skills and quality of bank employee. There are four measures within this dimension including; trustworthy staffs, promptness in service, willingness to handle problems and being available in responding customer request. Table 4 reports responses of 164 customers of the banks about these measures and descriptive statistics. 
Table 4

Descriptive Statistics Responsiveness Service Quality Dimension

\begin{tabular}{|c|c|c|c|c|c|c|c|c|c|}
\hline Responsiveness Measures & $\stackrel{\Xi}{\stackrel{\Xi}{ \pm ٍ ~}}$ & 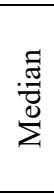 & 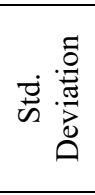 & 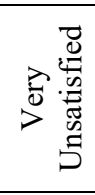 & 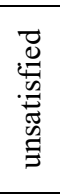 & $\begin{array}{l}\bar{\pi} \\
\stackrel{\vec{E}}{\Xi} \\
\bar{Z}\end{array}$ & 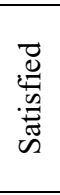 & 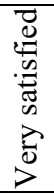 & $\stackrel{\pi}{\frac{\pi}{0}}$ \\
\hline $\begin{array}{l}\text { Traits of bank staff } \\
\text { (trustworthy, courteous and } \\
\text { have patience) }\end{array}$ & 3.6 & 4 & 0.804 & - & 16 & 58 & 74 & 16 & 164 \\
\hline Service delivery time of staff & 3.5 & 4 & 0.724 & - & 10 & 70 & 72 & 12 & 164 \\
\hline $\begin{array}{l}\text { Staff's willing to handling } \\
\text { problems (i.e. speed of problem } \\
\text { solving) }\end{array}$ & 3.2 & 3 & 0.883 & 4 & 28 & 64 & 60 & 8 & 164 \\
\hline $\begin{array}{l}\text { Staffs attitude to respond to } \\
\text { customer requests. }\end{array}$ & 3.6 & 4 & 0.666 & - & 8 & 60 & 88 & 8 & 164 \\
\hline Group Mean & 3.48 & & & & & & & & \\
\hline
\end{tabular}

The results displayed in the table have reported a mixed customer responses on four measures of responsiveness dimension. Out of four measures, responding customer request, trustworthy staffs and prompt services to customers achieve mean statistics more than 3.50 and almost of the respondents found to be satisfied with these measures in the bank service quality. However the measure indicating bank staff willingness handle problems has median of 3 clearly shows uncertainty about customer satisfaction in this measure. The group mean of this dimension is 3.48 is the lowest among five service quality dimensions used in the study.

\subsection{Assurance of SERVQUAL dimension of the banks}

Assurance is other service quality dimension that is reflected by employee attitude and behavior. More assurance for their services to customers is the key factor in generating positive customer attitude towards the bank and bank services. This study employed for measures of assurance as; employee behavior, safe transaction, courteous employee and employee knowledge. Table 5 depicts descriptive of the responses. 


\section{Table 5}

Descriptive Statistics of Assurance Service Quality Dimension

\begin{tabular}{|c|c|c|c|c|c|c|c|c|c|}
\hline Assurance Measures & $\sum_{\Sigma}^{\Xi}$ & 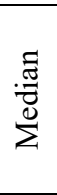 & 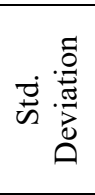 & 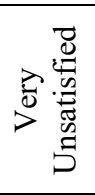 & 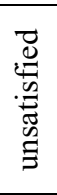 & $\begin{array}{l}\bar{\pi} \\
\text { 莺 } \\
\text { Z }\end{array}$ & 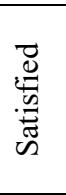 & 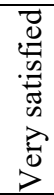 & $\underset{\stackrel{\pi}{0}}{\bar{\theta}}$ \\
\hline $\begin{array}{l}\text { The behavior of bank staff } \\
\text { to instills customer } \\
\text { confidence. }\end{array}$ & 3.8 & 4 & 0.806 & - & 12 & 40 & 86 & 26 & 164 \\
\hline $\begin{array}{l}\text { Customer feel safe in } \\
\text { transaction with the bank }\end{array}$ & 3.8 & 4 & 0.725 & - & 8 & 42 & 94 & 20 & 164 \\
\hline $\begin{array}{l}\text { The staff nature of } \\
\text { consistently courteous with } \\
\text { customers. }\end{array}$ & 3.7 & 4 & 0.618 & - & 4 & 50 & 100 & 10 & 164 \\
\hline $\begin{array}{l}\text { Knowledge of staffs to } \\
\text { answer customer questions. }\end{array}$ & 3.7 & 4 & 0.663 & - & 4 & 50 & 94 & 16 & 164 \\
\hline Group mean & 3.75 & & & & & & & & \\
\hline
\end{tabular}

This dimension has one of the highest mean and median values of 3.75 representing satisfactory presence of assurance as service quality in banking services. All four dimensions have more than 3.70 mean values indicating satisfaction of the customer as they perceived assurance from bank employee for pleasant transactions with the banks.

\subsection{Empathy SERVQUAL dimension of the banks}

In service quality, empathy poses important role to create a sense of belongings in the part of the customers with the organization. Empathy dimension in this study encompasses four measures. They are; individual attention, convenient operating hours, personal attention, and understanding specific needs of the customers. So this customer centered measures help to assess level of empathy of the bank service quality as responded by the customers. Table 6 depicts some descriptive statistics. 
Table 6

Descriptive Statistics of Empathy Service Quality Dimension

\begin{tabular}{|c|c|c|c|c|c|c|c|c|c|}
\hline Assurance Measures & $\sum_{\Sigma}^{\Xi}$ & 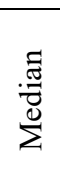 & 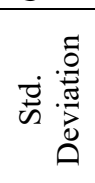 & 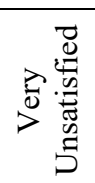 & 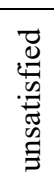 & 苛 & 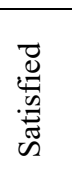 & 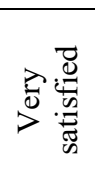 & 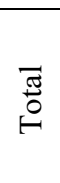 \\
\hline $\begin{array}{l}\text { The behavior of bank staff to } \\
\text { instills customer confidence. }\end{array}$ & 3.8 & 4 & 0.806 & - & 12 & 40 & 86 & 26 & 164 \\
\hline $\begin{array}{l}\text { Customer feel safe in } \\
\text { transaction with the bank }\end{array}$ & 3.8 & 4 & 0.725 & - & 8 & 42 & 94 & 20 & 164 \\
\hline $\begin{array}{l}\text { The staff nature of } \\
\text { consistently courteous with } \\
\text { customers. }\end{array}$ & 3.7 & 4 & 0.618 & - & 4 & 50 & 100 & 10 & 164 \\
\hline $\begin{array}{l}\text { Knowledge of staff to } \\
\text { answer customer questions. }\end{array}$ & 3.7 & 4 & 0.663 & - & 4 & 50 & 94 & 16 & 164 \\
\hline Group mean & 3.75 & & & & & & & & \\
\hline
\end{tabular}

As per the results as reported in Table 6, the empathy dimension of bank service quality is other dimension having highest group mean value of 3.75 and individual mean values of all four measures. The median values of all variables have indicated customer satisfaction in the measures used assess empathy in bank services. Among four measures, employee of the bank giving personal attention to customer has highest preference in the group.

\subsection{T-Tests of service quality dimensions of the study}

The One Sample t- test is conducted to analyze the satisfaction level of SERVQUAL which procedure tests whether the mean of a single variable differs from a specified constant. Table 7 depicts the constant test values of five dimensions of bank service quality.

This study aimed to examine the level of consumer satisfaction on five service quality dimensions namely; tangibles, reliability, responsiveness, assurance and empathy. Each of these dimensions consisted independent measures and the descriptive statistics with respondent's data of those measures were discussed in the previous sections. 
Table 7

t- test Statistics of Service Quality Dimensions used in the Study

Test Value $=0$

Dimensions of bank service quality

\begin{tabular}{llllll}
\hline $\mathrm{t}$ & $\mathrm{df}$ & $\begin{array}{l}\text { Sig. (2- } \\
\text { tailed) }\end{array}$ & $\begin{array}{l}\text { Mean } \\
\text { Difference }\end{array}$ & \multicolumn{2}{l}{$\begin{array}{l}\text { 95\% Confidence } \\
\text { Interval of the } \\
\text { Difference } \\
\text { Lower }\end{array}$} \\
& & & & \multicolumn{3}{l}{ Upper } \\
74.126 & 163 & .000 & 3.68293 & 3.5841 & 3.7818 \\
80.754 & 163 & .000 & 3.51951 & 3.4335 & 3.6056 \\
58.337 & 163 & .000 & 3.47561 & 3.3571 & 3.5942 \\
66.148 & 163 & .000 & 3.74695 & 3.6342 & 3.8597 \\
63.866 & 163 & .000 & 3.75305 & 3.6361 & 3.8700 \\
\hline
\end{tabular}

The t-test statistics in observed data regarding services quality dimensions have clearly resulted to the fact that all these dimensions of service quality are prevailing significantly in the banks of the study. Since the observed t-value of all these variables exceed the tabulated value and 2-tailed significance also have been found at zero for all the variables. In addition both lower and upper confidence intervals of the dimensions strongly suggest that the banks have all five dimensions significantly in their banking service quality.

\section{Conclusions}

This study intended to reveal the level of service quality provided by Nepalese banking firms from customer perspective. This study examined the perceived service quality the customers of the banks using the SERVQUAL model. The customer perceived satisfaction for five SERVQUAL dimensions were analyzed to assess aggregate service quality status of the banks. The descriptive and inferential analysis have indicated to the average level of customer satisfaction on all five service quality dimensions considered namely; tangibles, reliability, responsiveness, assurance and empathy. Among these five dimensions, empathy and assurance were more satisfied dimensions in bank service quality. Similarly tangibles as well as reliability were moderately and responsiveness was least satisfied dimension as perceived by bank customers. The finding of this study is consistent to findings of Afroz (2019); Alabboodi (2019); Ashraf and Venugopalan (2018); Ahemad (2017); and Van and Lee (2012). 
THE BATUK : A Peer Reviewed Journal of Interdisciplinary Studies $\quad$ Vol. 6 Issue No.1 $\quad$ Jan 2020 ISSN 2392-4802

The study has revealed the status of customer satisfaction about banking service quality of selected Nepalese commercial banks. The result provides some useful information that could help bank management to take appropriate initiations in maintaining better service quality. Although this study is limited in terms of the size and scope of its samples, it may provide some bases for future research in this area.

\section{References}

Afroz, N. N. (2019). Effect of service quality on customer satisfaction evidence from banks in Tangail. Management Studies and Economic Systems (MSES), 4 (2), 145-159.

Ahmed, M. (2017). Service quality measurement regarding banking sector. International Journal of Business and Social Science, 8 (6), 116-127.

Alabboodi, A. S. (2019). The effect of customer satisfaction on service quality: The case of Iraqi banks. International Journal of Applied Research, 5 (1), 146152.

Ashraf, E., \& Venugopalan, K. (2018). Service quality and customer satisfaction: A comparison between public and private sector banks in Kerala. International Journal of Research and Analytical Reviews, 5 (3), 567-572.

Bedi, K. (2014). Quality management (1 $1^{\text {th }}$ ed.). Oxford University Press, New Delhi.

Bhat, K. S. (2012). Total quality management. Himalayan Publishing House, Mumbai.

Cronin, J. J., \& Taylor, S. A. (1992). Measuring service quality: A re-examination and extension. The Journal of Marketing, 56, 55-67.

Crosby, P. B. (1979). Quality is free: The art of making quality certain. New York: New American Library.

Garvin, D. A. (1983). Quality on the line. Harvard Business Review, 61 (5), 64-75.

Gronoos, C. (1984). A service quality model and its marketing implications. European journal of Marketing, 18 (4), 36-44.

Gronroos, C. (1978). A service-oriented approach to marketing of services. European Journal of Marketing, 12 (8), 588-60.

Gronroos, C. (1983). Strategic management and marketing in the service sector. Cambridge, MA: Marketing Science Institute.

Gronroos, C. (1990). Service management and marketing: Managing the moments of truth in service competition. Lexington, MA: Lexington Books. 
Khondaker, M. S., \& Mir, M. Z. (2011). Customer satisfaction measurement for the state-owned banks in the developing countries - The case of Bangladesh . Journal of Business and Policy Research, 6 (2), 153-172.

Parasuraman, A., Zeithaml, V. A., \& Berry, L. L. (1988). SERVQUAL: A multiple-item scale for measuring consumer perceptions of service quality. Journal of Retailing, 64 (1), 12-40.

Parasuraman, A., Zeithaml, V. A., \& Berry, L. L. (1985). A conceptual model of service quality and its implication for future research. Journal of Marketing, 49, 41-50.

Van, D., \& Lee, P. (2012). Examining service quality and customer satisfaction in the retail banking sector in Vietnam. Journal of Relationship Marketing, 11,199-214. 